\title{
Author Correction: In situ conversion of defective Treg into SuperTreg cells to treat advanced IPEX-like disorders in mice
}

Yongqin Li(1), Yuxin Chen, Shaoshuai Mao, Ravinder Kaundal, Zhengyu Jing, Qin Chen, Xinxin Wang, Jing Xia, Dahai Liu, Jianlong Sun, Haopeng Wang (1) \& Tian Chi (D)

Correction to: Nature Communications https://doi.org/10.1038/s41467-020-15836-2, published online 03 June 2020.

The original version of this Article omitted the following from the Acknowledgements:

We thank the Molecular and Cell Biology Core Facility (MCBCF) at the School of Life Science and Technology, ShanghaiTech University, for providing technical support.

This has now been corrected in both the PDF and HTML versions of the Article.

Published online: 08 April 2021

(c) (1) Open Access This article is licensed under a Creative Commons Attribution 4.0 International License, which permits use, sharing, adaptation, distribution and reproduction in any medium or format, as long as you give appropriate credit to the original author(s) and the source, provide a link to the Creative Commons license, and indicate if changes were made. The images or other third party material in this article are included in the article's Creative Commons license, unless indicated otherwise in a credit line to the material. If material is not included in the article's Creative Commons license and your intended use is not permitted by statutory regulation or exceeds the permitted use, you will need to obtain permission directly from the copyright holder. To view a copy of this license, visit http://creativecommons.org/licenses/by/4.0/.

(C) The Author(s) 2021 